\title{
Correction to: Effect of the Printing Orientation on the Mechanical Properties and Thermal and Electrical Conductivity of $\mathrm{ABS}-\mathrm{ZnFe}_{2} \mathrm{O}_{4}$ Composites
}

Khairul Amali Hamzah, Yeoh Cheow Keat, Mazlee Mohd Noor, Teh Pei Leng, Shulizawati Aqzna Sazali, Aw Yah Yun, and Wan Mohd Arif Wan Ibrahim

Correction to:

JMEPEG (2019) 28:5860-5868

https://doi.org/10.1007/s11665-019-04313-7

The following correction should be noted to the Acknowledgments section of this article.

\section{Acknowledgments}

The Grant Number given as "FRGS/2/2014/ICT06/UNIMAP/ 02/3" should instead read "FRGS/1/2018/TK05/UNIMAP/02/14."

Publisher's Note Springer Nature remains neutral with regard to jurisdictional claims in published maps and institutional affiliations.

The original article can be found online at https://oi.org/10.1007/ s11665-019-04313-7.

Khairul Amali Hamzah, Yeoh Cheow Keat, Mazlee Mohd Noor, Teh Pei Leng, Shulizawati Aqzna Sazali, Aw Yah Yun, and Wan Mohd Arif Wan Ibrahim, School of Material Engineering, Universiti Malaysia Perlis (UniMAP), 02600 Jejawi, Perlis, Malaysia. Contact e-mail: amalyhamzah@gmail.com. 